\title{
The Effect of Hot Money Flow on Pre-Crisis Indicators of Current Accounts and Real Sectors in Turkish Economy ${ }^{1}$
}

\author{
Ömer Uğur Bulut², Sadık Rıdvan Karluk ${ }^{3}$
}

\begin{abstract}
We investigate the impact of the hot money movements on current account and real sector leading crisis indicators under VAR (Vector Autoregressive) framework using quarterly data for a long period of 1991-2014. Our findings show that hot money movements have negative impact on current account deficit and foreign trade deficit pre-crisis indicators. We further show that they lead to instability in growth and inflation pre-crisis indicators.
\end{abstract}

Keywords: Hot money movements, pre-crisis indicators, Turkish economy, VAR model.

Available Online: 28-11-2016

This is an open access article under Creative Commons Attribution 4.0 License, 2016.

\section{0}

\section{INTRODUCTION}

The hot money flow is an important part of the financial liberalization policies, applied during the 1980s in world economy. This concept, revealed its affect with the abolition of the restrictions on capital movements and the permission given to the residents to access to the financial markets. As suggested by (McKinnon, 1973) and (Shaw, 1973) in their financial liberalization hypothesis; the financial pressure policies such as restricting the movement of capital could contribute to the economic development and cause more effective distribution of the resources. Between the years of 1980 and 1990, affected by these ideas, many countries have applied the financial liberalization policies. However, except in some of the South-East Asia countries, in most of the countries, these policies became unsuccessful (Williamson, Mahar, 2002). Hence, the increase in the global saving pools means the increase of risk and uncertainty in the foreign capital, which is flowing to the countries.

From the 1980s, the liberalization programs supported by International Monetary Foundation (IMF) paved the way for foreign capital which hot money flow has an important part in. However, as in Latin America and South East countries this caused crisis also in Turkey. The foreign capital inflow is

\footnotetext{
1 This article has been written by benefiting from the "Financial Liberalization and Pre-Crisis Indicators Analysis" named doctoral dissertation which has been written with the dissertation consultant Prof. Dr. S. Rıdvan Karluk

2 Philosophy of Doctorate, E-mail: bulut.o.u@gmail.com

3 Professor (retired), E-mail: rkarluk@anadolu.edu.tr
} 
important for countries, which are continuing their industrial development but its negative effects leads up to economic and financial crisis. As emphasized by some researches -such as Kaminsky, Lizondo and Reinhart's research on KLR approach which is the widely-used method in economy literature about pre-crisis indicators- the pre-crisis indicators bear the qualification of signaling in predicting the crisis. There are other studies includes (Frankel, Rose 1996) and (Corsetti, Pesenti \& Roubini, 1998). Considering the number of studies and meaningful number of statistical results, the current accounts and real sector pre-crisis indicators are prominent. On the other hand, in studies related to hot money movement in economy literature includes (Corbo, Hernandez 1996), (Yeldan, 1996) and (Rodrik, Velasco 1999) show that the meaning of this concept has not been defined clearly. It is often defined within the short-term capital movement. The number of empirical studies is also low.

By assessing these results in literature, in our study, the positive and negative effects of hot money on the current account and real sector indicators and its usability as a political tool have been studied with vector autoregressive model (VAR). By using the VAR model the effect of hot money movement in precrisis indicators of current accounts and real sector in Turkish economy, after year 1991 is analyzed. The sample and data used in econometric analysis section were chosen by considering the performances of pre-crisis indicators in the study of (Kaminsky, Lizondo \& Reinhart, 1998) and collected from the web sites of Turkish Central Bank (TCB), Turkish Statistical Institute (TSI) and International Financial Statistics (IFC). The results will provide important hints and opinion to the policy makers on the efficiency and usability of one of the important parts of financial liberalization policy; the hot money flow policy tool, in management of the Turkish economy. The financial liberalization policy of the Turkish economy will be able to directed against hot money movements. Within this purpose, the hot money flow in Turkey is discussed firstly. And then, after expressing the review of literature and precrisis indicators, the econometric model application is reported.

\subsection{THE HOT MONEY FLOW IN TURKISH ECONOMY}

Before the 1980, the Turkish economy faced; macroeconomic instability, the problem of financing of balance of payments deficit, the high inflation and high foreign debt (important part of it being shortterm), the imports bottleneck and stagnation of exports. During 1970 s it has highly been affected by the global crisis and there had been disruption in macroeconomic indicators and problems in foreign debt payments. This situation caused the criticism of import-substitution policies and lead to the search for alternative policies. Thus, with the $24^{\text {th }}$ January 1980 dated Decisions, the foreign financial liberalization policies put in effect. The Turkish economy completed its financial liberalization period with the foreign trade liberalization in 1980 and the abolition of restrictions on the foreign capital movement in 1989. At the end of this period, in which the final steps been taken to be in harmony with the global economy, many crises occurred with different reasons and results.

The movement of capital occurs when; the resident individuals or institutions of one of the country transfer funds to the resident individuals or institutions of another country (Uzunoğlu, Alkın \& Gürlesel, 1995). The permission of freedom of movement of capital in Turkey occurs when foreign residents move the actively in financial markets of Turkey buying stocks and bonds in Turkey, and similarly, the residents of Turkey having the right to perform the same transactions in foreign countries.

The movement of capital can be classified as short-term or a long-term based on the time frame that the capital stays in the country for the development purposes, technical purposes, defense and commercial purposes. The movement of capital provides financial and technological resources to the country, by lending, investment or by joining to the process of production.

The movement of capital can be seen in capital account section of balance of payment of countries. The abolition of restrictions on these movements means the liberalization of the capital account. The movement of capital in Turkey reveals its effect with hot money flow.

In 1989, because of the financial liberalization, the freedom of movement of capital and the increasing need of borrowing brought up the topic of hot money flow and it is one of the important part of the 
movement of capital in Turkish economy. Turkey faced the negative effects of abolition of restrictions on movement of capital firstly, in year 1994. In 1994 and after, in global crisis of November 2000, February 2011 and 2008, a huge amount of hot money out flowed the country (Karluk, 2014).

In economy, there is no general definition of hot money. It is one of the short-term capital movements. However, since the hot money inflows rapidly for profit purposes and outflows in a minor negativity in economy, compared to short term capital, it is vague, speculative and have a high potential of risk. The concept of hot money can be explained as a capital investment which rapidly reacts to the changes in expected income rate and risks (Oktar, 1995). According to another definition, the hot money is the short-term capital flow which have speculative, short term, risk and mobilization components and is a short-term capital movement investing with factors of high risk and income arising from the difference between interest and foreign currency rates in the national markets (Yeldan, 1996). In other words, the hot money, is the short-term money, flowing to the country except by exports, tourism or foreign direct investment, and flowing from two windows; the short-term lending and portfolio investments.

The Turkish economy became vulnerable to economic crisis with the abolition of restrictions on movement of foreign capital. The hot money inflow based on arbitrage about income, the interest rates and expected foreign currency rates, leads the economy into crisis. After 2002, the floating exchange rate system was not able to prevent the outflow of hot money because of the elasticity provided by the forward foreign exchange market (Boratav, 2009).

As can be seen in Table 1, most of the economic crises occurred because of the rapid slowdown of capital inflow or the opposite. The period after the liberalization of capital movement, as revealed in Table 2, the fundamental reason behind the fluctuation in growth is the foreign originated capital movement. In each of periods that the capital inflow slowed down or move oppositely $(1994,2001)$ the growth rate declined and became negative. As can be seen in Table 2, the positive average growth rate of which is more than $5 \%$ caused the current deficit growth and more foreign capital inflow occurred to finance the deficit. Hence, in the years when the capital movement was controlled the foreign capital inflow been used to finance the current deficit.

The period after 1989, in which the movement of capital been liberalized, the reason of short term expansion, in other words the increase in growth, was the increase in foreign capital, which largely includes hot money movement. After The period of 1998-2001, which includes the years of recession and depression, the most effective variable initiating the years of expansion was foreign origin capital inflow (Boratav, 2009). The foreign capital inflow initiates the expansion of demand in any condition. As can be seen in Table 2, triggered by the reasons mentioned, the expansion of demand or short term growth causes the increase in current account deficit starting from the foreign trade balance.

Table 1: The foreign capital movement in pre-crisis and crisis years

The Crisis Years The Foreign Capital Inflow one year before the Crisis (Million

The Foreign Capital

USD) Inflow In the year of Crisis

12079 (Million USD)

1994 Crisis

15726 $-3925$

2000/2001 7568 $-3837$

Crisis

2008 Crisis

75684 $-10894$

As stipulated in Table 2, after 2001 crisis, the high rate of capital inflow ended with 7,2\% growth rate, the current account deficit, increased up to 6\%. In 2001 crisis an opposite situation occurred. The foreign capital increased in high rate, compared to the year before the crisis and caused $-9,5$ growth rate, which was the lowest after the second World War. However, the current deficit occurred 2,6\% more, compared to the pre-crisis years. The increase in current deficit became chronic in 2000s. The appreciation of Turkish Lira, the effects of Customs Union and the transformation of structure of industry towards external dependence have influence on this situation (Boratav, 2009). On the other 
hand, as can be seen in Table 2, between the years of 2002-2007 the high increase in inflow of foreign capital became most effective factor in current deficit financing. Rapidly growing foreign debt is the common reason of the negative relation of current deficit and growth and the effect of foreign capital on them. In Table 2, during 2000s, since the current deficit increased in relation to the growth, the foreign inflow of capital increased more in 2000 s compared to 1990 s.

\begin{tabular}{lrrrr}
\hline \multicolumn{5}{c}{ Table 2: The foreign capital movement, the current deficit and growth (\%) } \\
\hline Year & Foreign Capital Movement/ GDP & Current Deficit / GDP & Growth Rate \\
\hline 1984-1988 & 2,2 & $-0,8$ & 6,2 \\
1989-1993 & 3,3 & $-1,2$ & 5,0 \\
Crisis: 1994 & $-4,8$ & 2,0 & $-6,08$ \\
$1995-1997$ & 3,4 & $-1,4$ & 7,7 \\
$1998-1999$ & 3,0 & 0,3 & $-1,2$ \\
2000 & 8,1 & $-4,9$ & 6,3 \\
Crisis: 2001 & $-1,7$ & 2,6 & $-9,5$ \\
2002-2007 & 9,8 & $-5,8$ & 7,2 \\
\hline
\end{tabular}

Table 3 reveals that, when the inflow of foreign capital is compared in years of 1994, 2000,2001 and 2008 , both before and after the years of crisis, it can be seen that; the foreign capital act reversely (the sign of - reveals the outflow). This Table also stipulates that the Turkish economy dragged into unsteady growth period in the years (1989-2007) that the liberalization of foreign capital started. While the economic growth was $-9,5 \%$ in year 2001, it was 7,2\% on average, in the period of 2002-2007. (Table 2 and Table 3). These two data demonstrate the unsteady growth of capital in Turkish economy and the dependency to the foreign capital movement between the years of 1989-2007. While Turkey grows 3,6\% on average, the sharp up and down cycle that is experiences, increased the negative expectations on uncertainty, risk in investments and growth in relation to future.

In 2008 crisis, the foreign capital movement has affected the economy as in the crisis of 1994, 20002001. If we compare the intensity of the effect, in the 2008 crisis the foreign capital outflow was higher compared to the other crisis. As can be seen in Table 3, during the 12 months before the year 2008, the foreign capital inflow was 76 billion USD. On the other hand, the foreign capital inflow before the crisis in years of 1994 and 2011 was approximately 28 billion USD. The high foreign capital inflow that occurred in year before the 2008, compared to the years before the other two crisis years caused higher rate of capital outflow in the months of crisis. In relation to the its effect on growth rate of Turkey if we compare the 2008 crisis with other crisis that occurred, we can see that 2001 crisis has the heaviest effect. In relation to growth, the 1994 crisis negative effect was 6,08\% and 2008 crisis negative effect was 4,8\% however, in 2001 crisis the Turkish economy downsized by $9,5 \%$.

Table 3: The foreign capital movement in 1994, 2000-2001, 2008 global crisis and pre-crisis years

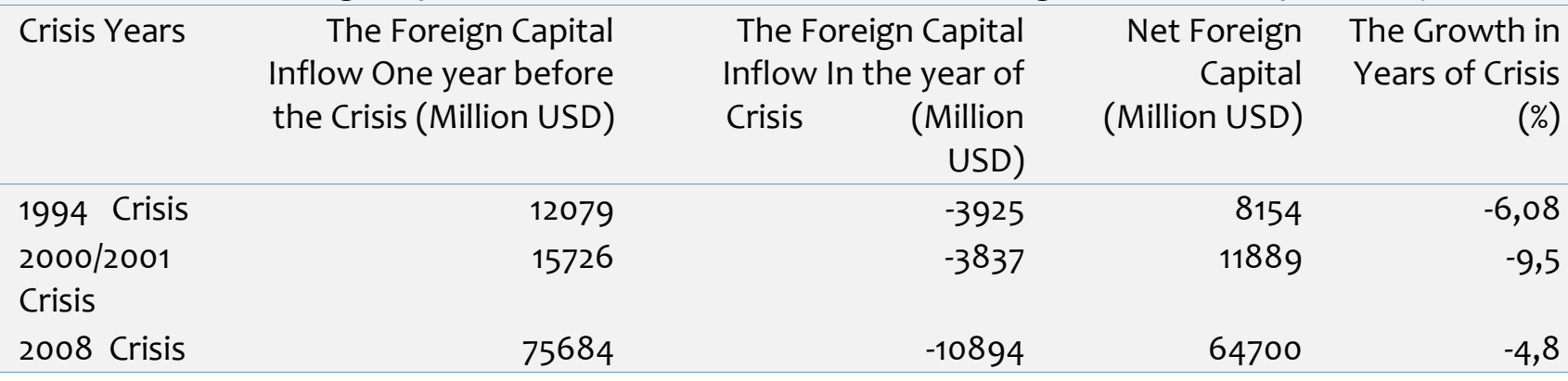

As can be seen in the Table 4, the main indicator of crisis in Turkey is the outflow of foreign capital and it is 5,4 billion USD net in October 2008, as in 1994 and 2000-2001 crisis. Compared to the 1,654 billion USD net inflow in October 2007, in year 2008 there is a back flow of approximately 7 billion USD. When 
we analyze the net capital movement, the foreign net inflow realized but compared to the previous year it dropped to 1,142 billion USD in October 2008. The reason of net capital movement being in surplus is the approximately 7,4 billion USD unrecorded capital inflow from an unaccredited source.

The other prominent indicators in Table 4 are; national capital and hot money. In October 2008, 851 million USD national capital, approximately 3 billion USD national hot Money and 5,6 billion USD foreign hot Money outflow was realized. In total, approximately 7,6 billion USD net hot money outflowed from Turkish economy. The decline of foreign capital not only affected the slowdown of national income but also contributed to the decrease of national income. The increase in outflows leads to financial crisis even if there is unrecorded capital inflow (Boratav, 2011).

Table 4: The foreign capital movement, October 2007 - 2008 (Million USD) October 2007 October 2008

$\begin{array}{lr}\text { Foreign Capital } & 1654 \\ \text { National Capital } & 2510 \\ \text { Unrecorded Capital } & -1046 \\ \text { Net Capital } & 3118 \\ \text { Foreign Hot Money } & -358 \\ \text { National Hot Money } & 3053 \\ \text { Net Hot Money } & 2695\end{array}$
$-5390$ $2510 \quad-851$ $-1046 \quad 7383$ 3118 $-358-5558$ $3053-2016$ 2695 $-7574$

In 2008 crisis, the net capital movement decreased while the foreign capital outflow occurred in high rate. As can be seen in Table-4, the 7,4 billion USD unrecorded capital inflow compensated the outflow of foreign capital. In that reason, there is a "decline" in the net capital movement and not a "net outflow". As can be seen at Table 5, until October 2008, in economy, the foreign capital inflow continued in an increasing way despite the global crisis. In October 2008, approximately 5,4 billion USD outflow occurred. As can be seen from the data of November 2008 and November 2009, the outflow of foreign capital from Turkish economy continued until November 2009. After in October 2008 the reverse cycle (the conversion of foreign capital from inflow to outflow) ended.

In Table 5, it can be seen that, the foreign capital; from its 4,4 billion outflow in November 2008, changed into 786 million USD inflow in 2009. The net capital increased by 993 million USD. From the 2009 November data laid out in Tablo-5, it can be seen that, the external shock caused by the October 2008 capital movement ended in November 2009.

The Table 3, Table 4 and Table 5 reveals that, after the year 1989, in which the capital movement is liberalized in Turkey, the expansion of economy in Turkey became dependent on the foreign source inflow. When the capital inflow standstills, the contraction occurs and when the inflows changes into net outflow, the financial crisis comes up. The Tables in this section presents the dimensions of the external shocks arising from the capital outflow.

Table 5: The foreign capital movement: October 2007, October 2008, November 2008 and November 2009 (Million USD)

\begin{tabular}{lrrrr}
\multicolumn{5}{c}{ November 2009 (Million USD) } \\
& October 2007 & October 2008 & November 2008 & November 2009 \\
Foreign Capital & 1654 & -5390 & -4357 & 786 \\
National Capital & 2510 & -851 & 3379 & -743 \\
Unrecorded Capital & -1046 & 7383 & 1064 & 1036 \\
Net Capital & 3118 & 1142 & 86 & 1079
\end{tabular}

After the abolition of restrictions on the foreign capital, the markets in Turkey started to be controlled by the short term speculative foreign capital. As an effective crisis indicator; the hot money that bear the risk of leaving the country in any minor negativity, entered into the economic environment which 
already has important macro-economic instabilities such as current deficit and high inflation and the hot money played an important role in economic problems encountered after 1989. In addition to the macroeconomic instabilities and political uncertainty; the environment where the state intervention is minimized, the stability of the economy dangerously been risked by the speculative movement of foreign capital inflow and outflow [10]. After the liberalization of movement of capital, the Turkish economy became vulnerable to crisis. The crisis which have been experienced after 1989, such as the crisis of 1994, 2000-2001 and 2008 are the known examples of this situation. In an already negative environment the regulation of liberalization, lead up to the increase in crisis.

\subsection{THE REVIEW OF LITERATURE}

The idea of "hot money movement creating instability in economies of countries", lead to the performance of studies on this subject. The studies on the short term capital movement which the hot money flow is part of, (Corbo, Hernandez 1996), (Yeldan, 1996) ile (Rodrik, Velasco 1999) defended that; the short term capital inflow causes instability and crisis in economy and should be restricted when necessary. In their study on the effects of movement of capital on fundamental macro-economic indicators on the period of years between 1989 and 1999 in Turkish economy, (Insel, Sungur 2003), with the real and financial indicators revealed that the movement of capital causes instability in economy. (Altıntaş, Öz, 2007), in their study on the 1994 and 2001 Turkish economy crisis, by using the signaling approach, presented that the capital outflow can be used as a pre-crisis indicator. In their study, (Mercan, Peker, 2013) used portfolio investments and capital inflow as representing the financial openness, although these indicators found to be affecting the growth in positive way, they were found to be statistically meaningless.

There are also some other studies focusing on pre-crisis indicators of Turkish economy including the current accounts and real sector indicators performed. (Üçer, Rijckeghem \& Yolalan, 1998), in order to analyze the 1994 crisis, applied the KLR test. In the study, they presented that the export/import, shortterm foreign debt/GDP, short term advances/GDP, reserves/M2Y+debt stock and M1 indicators found successful in predicting the financial crises. (Gerni, Selçuk \& Değer, 2005), in their study on the Turkish economy crisis, with their pre-indicator approach, reached to the conclusion that the overvaluation of national money is a pre-crisis indicator. (Avcl, Altay 2013), in their study, they used the monthly data of 1990-2009 and the Markov Regime Switching Model and Regression Tree Models and they proved that the inflation and foreign trade balance indicators are successful in predicting financial crisis.

In our study, we aimed to analyze the effect of hot money on the current account and real sector precrisis indicators. For this purpose, the objectives can be expressed as follows: (1) How are hot money movements affecting the current account and real sector pre-crisis indicators? (2) How is the efficiency of hot money movements on current account and real sector pre-crisis indicators?

\subsection{PRE-CRISIS INDICATORS}

In the studies performed to assess the economic and financial crisis, the change in the macroeconomic indicators such as; the decline in international reserves, real interest rates, the increase in short term debt, national inflation, current deficit and the imbalance of foreign trade, the decrease of growth rate signals the financial crisis. (Frankel, Rose 1996), (Kaminsky, Lizondo, Reinhart, 1998), and (Corsetti, Pesenti \& Roubini, 1998) try to determine the crisis with indexes calculated by using different methods (Seyidoğlu, Yıldız, 2006). This approach for the economic and financial crisis caused others to focus on the studies related to the pre-crisis indictors.

Among the studies on determination of these indicators, the most important and comprehensive one is the approach of (Kaminsky, Lizondo \& Reinhart, 1998) which is called KLR approach and performed by using the signaling method. The mentioned study has been performed by using the monthly data of years between 1975 and 1995 of fifteen developing and five developed countries. According to KLR study, when one of the macroeconomic indicators is above the threshold, it is a sign that indicates a 
possible financial crisis in the following 24 months (Karaçor, Alptekin, 2006). As a pre-crisis indicator of current account, the current account deficit, the foreign currency rate and foreign trade balance and as a pre-crisis indicator of real sector; growth rate and inflation have been designated as important crisis indicators (Kaminsky, Lizondo \& Reinhart, 1998).

The fundamental goal of the pre-crisis indicator approach is to assess the crisis before they occur. For this purpose, the signals of designated variables are analyzed within a certain period. The crisis signal occurs when, one of the variables designated as a crisis indicator is above the set threshold (Çeviş, 2005). The study which is named as KLR approach in literature, can be seen on Table 6, where the current balance and real sector pre-crisis indicators performance has been analyzed (Kaminsky, Lizondo \& Reinhart, 1998).

In our study; the pre-crisis indicators used in econometric analysis section were chosen by considering the performances of pre-crisis indicators in Table 6 chosen in the study of (Kaminsky, Lizondo \& Reinhart, 1998). In relation to the current accounts and real sector pre-crisis indicators, we have considered the studies quantity being excessive and statistical meaning of them. In that manner, as a pre-crisis indicator of current account, the foreign currency rate, the current account deficit, and foreign trade balance deficit and as a pre-crisis indicator of real sector; growth rate and inflation have been used.

The decrease in foreign currency rate is an indicator of change of value of national Money. The overvaluation of national money destabilizes the current accounts. These valuations cause the outflow of capital from the country hence it is expected to increase before the crisis (Avcl, Altay, 2013). The overvaluation of national money increases the probability of occurrence financial crisis (Turgut, 2007). The increase in exports is a sign of loss of completion in international markets, the decrease in exports may be the result of overvaluation of national money. The foreign currency assets can cause risks for the banks that are in breach of their obligations. The increases in imports occur in line with the weak foreign markets and overvaluation of national money and is one of the reasons of money crisis (Altıntaş, Öz, 2007). The deterioration of trade balance increased the expectation of devaluation so it's expected to decrease before the crisis (Avcl, Altay, 2013).

Table 6: The economic pre-crisis indicators and their performances

\begin{tabular}{llrr}
\hline Sector & Variables & $\begin{array}{r}\text { The Number of } \\
\text { Studies Analyzed }\end{array}$ & $\begin{array}{r}\text { Statistically } \\
\text { Meaningful Results }\end{array}$ \\
\hline Current & Foreign currency rate & 14 & 2 \\
Accounts & Current account balance Trade & 7 & 2 \\
& Balance & 3 & 2 \\
& Export & 3 & 2 \\
& Import & 2 & 1 \\
& Terms of Trade & 3 & 2 \\
& Export Prices & 1 & - \\
& Savings & 1 & - \\
& Investment & 2 & - \\
& Currency rate Expectations & 1 & 5 \\
Real Sector & Inflation & 5 & 5 \\
& Real GDP growth or level & 9 & 1 \\
& Output Gap & 1 & 1 \\
& Employment/ Unemployment & 3 & 1 \\
& Change in Bond Prices & & 2 \\
& & 1 & \\
& & &
\end{tabular}

The current account having a negative value in a country means that the exports cannot meet the imports and this leads the country to use borrowing to clear this deficit. The increase in borrowing and 
capital outflow, in relation to the sustainability of the debt may deepen the current account deficit problems of the country (Altıntaş, Öz, 2007).

The decline of the growth rate is also a Real sector pre-crisis indicator and it increases the vulnerability in economy (Avcl, Altay, 2013). Before the crisis, the decline of growth rate is expected (Kaminsky, Lizondo \& Reinhart, 1998). The inflation moves parallel to the high nominal interest rates and by negatively affecting the economy, it increases the vulnerability in economy. Hence, the increase of inflation is also expected (Avcl, Altay, 2013).

\subsection{THE ECONOMETRIC MODEL APPLICATION}

The data for our econometric application been collected from the web sites of Turkish Central Bank (TCB) Turkish Statistical Institute (TSI) and International Financial Statistics (IFC). The Eviews 8.0 packaged software been used. In that manner, the three-month-data used and application made for the years between 1991-2014. Since the foreign capital inflow increased in high rate in 1991 in Turkey, that year has been used for beginning.

The VAR model is an appropriate model since it can designate the efficiency and usability of the indicators as a policy tool. The designation of most effective variance on the macro-economic indicators is determined with the variance decomposition and the efficiency and usability of this effective variance as a policy tool is determined by cause and effect functions (Sevüktekin, Nargeleçekenler, 2010).

In order to clear the seasonality effect on the time series of variables, "Tramo Seats" and "Moving Average" method been use and the time series of variables has been transferred into logarithmic form. However, since the cab, hmm and open variables became negative in some periods, their logarithmic transformation have not been performed. In the following phase, the Zivot-Andrews unit root test has been applied to determine whether the variables are stable or not. At this point the classical unit root tests such as ADF is criticized since these tests have tendency to find unrealistic unit root when there is structural breaks. (Zivot, Andrews 2002) developed the Zivot-Andrews test, which designates the structural breaks in the predicted period, and perform the unit root test. Zivot-Andrews test designates the structural breaks of variables internally.

Zivot-Andrews unit root test results are presented in Table 8. According to the results in Table 8 in the model including stable and trend in the $5 \%$ significance level, the values of cab, hmm, open levels are high so they are stable. In the light of these results; based on the Zivot and Andrews unit root test results, the pre-crisis indicators of real sector which are growth (rgdp) and inflation (inf) will be in VAR model with their first differences. Also, based on the Zivot-Andrews unit root test results the pre-crisis indicators of current account which are current account (open), foreign trend deficit (open) with their level values and foreign currency exchange rate (e) with its first difference will be in VAR model. The hot money movement ( $\mathrm{hmm}$ ) also with its level value will be in VAR model.

Table 7. The indicators used in econometric application

$\begin{array}{ll}\text { The Real Sector Pre-crisis Indicators } & \begin{array}{l}\text { The Current Account Pre- } \\ \text { crisis Indicators }\end{array} \\ \text { The Growth (rgdp) } & \begin{array}{l}\text { Curent Account Movement } \\ \text { crisis Indicators } \\ \text { (cab) }\end{array} \\ \text { Inflation (inf) } & \begin{array}{l}\text { Foreign Currency Exchange } \\ \text { Rate (e) }\end{array} \\ & \text { Foreign Trade Deficit (open) }\end{array}$

In the VAR model after determining the stability of the variables (whether they are stable or not) the other test that should be applied is the appropriate test to designate the lag-length. After that, it is important to apply variance and autocorrelation test and examine the characteristic roots, in order to 
determine whether the VAR model is stable or not. The lag-length test results based on the VAR model information criteria are presented in Table 9. The optimal lag lengths can be designated with Akaike, Schwarz and Finite Prediction Error information criteria (Gujarati, 2003). As long as there is no structural problem in the model (such as changing variance and autocorrelation) the leg-lengths that these kind of information criteria refer are used in general.

Table 8: The results of zivot - andrews unit root test

$\begin{array}{lrr}\text { The Variables } & \begin{array}{r}\text { Break in Stable } \\ \text { and Trend }^{\mathrm{a}}\end{array} & \text { Stability } \\ \text { Current Account Balance (cab) } & -5.46(2001 \mathrm{Q} 1) & \mathrm{I}(0) \\ \text { Foreign Currency Exchange Rate (e) } & -4.63(2001 \mathrm{Q} 1) & \mathrm{I}(1) \\ \text { Foreign Trend Deficit (Open) } & -5.14(2001 \mathrm{Q} 1) & \mathrm{I}(0) \\ \text { Growth (rgdp) } & -3.74(2002 \mathrm{Q} 1) & \mathrm{I}(1) \\ \text { Inflation (inf) } & -3.91(2003 \mathrm{Q} 3) & \mathrm{I}(1) \\ \text { Hot Money Movement (hmm) } & -5.21(2010 \mathrm{Q} 1) & \mathrm{I}(0)\end{array}$

a. For the break in stability in $1 \%, 5 \%$ and $10 \%$ significance level are (in order) $-5.34,-4.93$ and -4.58 . The values in break in trend are (in order) $-4.80,-4.42$ and -4.11 . The break in stability and trend are (in order) $-5.57,-5.08$ and -4.82 . The dates shown in parenthesis show years of the break.

In Table 9 the according to LR, FPE and AIC the lag-length is 4. In this lag-length, there is no change in variance and autocorrelation and all the roots are within the circle, so there is no structural problem in the model. The VAR (4) model is stable and consistent.

Table 9: VAR model designation of lag-length criteria

\begin{tabular}{lrrrrr}
\hline Lag & LR & FPE & AIC & SC & HQ \\
0 & NA & $5.66 e+54$ & 143.1008 & 143.2769 & 143.1715 \\
1 & 282.4996 & $3.16 e+53$ & 140.2122 & $141.4449^{*}$ & $140.7071^{*}$ \\
2 & 37.59462 & $4.47 e+53$ & 140.5454 & 142.8347 & 141.4645 \\
3 & 46.56811 & $5.32 e+53$ & 140.6843 & 144.0302 & 142.0276 \\
4 & $114.1564^{*}$ & $1.85 e+53^{*}$ & $139.5596^{*}$ & 143.9621 & 141.3271 \\
5 & 35.68127 & $2.49 e+53$ & 139.7380 & 145.1971 & 141.9297 \\
6 & 42.29703 & $2.81 e+53$ & 139.6761 & 146.1918 & 142.2921 \\
7 & 19.01674 & $5.46 e+53$ & 140.0665 & 147.6389 & 143.1067 \\
8 & 27.26576 & $8.63 e+53$ & 140.1183 & 148.7473 & 143.5827 \\
\hline
\end{tabular}

* refers the lag-length chosen by information criteria, LR: The likelihood rate; FPE: Finite Prediction Error Criteria AIC: Akaike Information Criteria; SIC: Schwarz Information Criteria; HQ: Hannan - Quinn Information Criteria

In VAR model, the cause and effect functions that are produced with "Cholesky decomposition" method, can be changed based on the order of variables. The order of the variables that are entered into the model should be made starting from external and after internal. The order is designated by the previous knowledge on the variables (Tarı, 2015).

In the cause and effect functions that are designated by using these methods, to define the standard errors the Monet Carlo simulation technique been used and for the point predictions (cause and effect results) the standard errors with 100 iterations are calculated. In Figure 1 the reaction of current account and real sector pre-crisis indicators to the shocks in hot money movement can be seen. The broken lines show the standard errors and the straight lines show the cause and effect results. The results below the zero reveal the negative reactions and the values over the zero reveal the positive reactions.

In order to assess the shocks that will be applied to the hot money flow; the movement of the variables during 10 periods been examined. In Figure 1 the reaction of the pre-crisis indicators of current account 
and real sector to hot money flow in 1 standard deviation of error terms is given. The results give information on the negative and positive effects of hot money movement on pre-crisis indicators of current account and real sector

In Figure 1 the reaction of the pre-crisis indicators of current account; the current account deficit (cab) and foreign trade deficit (open) to hot money movement $(\mathrm{hmm})$ is negative in the beginning. The negative effect continues during the period. The effect of both cab and open variable to hmm is negative during 10 periods and the approach towards positive after second and sixth period is totally limited. The hot money movement has negative and increasing effect on pre-crisis indicators of current account; the current deficit and foreign trade deficit. The reaction of foreign exchange rate (e) to hmm is (as in other pre-crisis indicators of current account) negative in the beginning, after the fifth period it reacts up and down and after eighth period it returns to negative again. The results in the Figure 1 reveal that the hot money movement affects another pre-crisis indicator current account foreign exchange rate negatively at the end of 10 periods in general. According to VAR (4) model, the hot money movement cannot be used as policy tool for current account pre-crisis indicator because it does not have any positive effect on these indicators.

Figure 1: The reaction of pre-crisis indicators of current accounts and real sector to shocks that are generalized one standard deviated hot money movement ( \pm 2 S.E.)
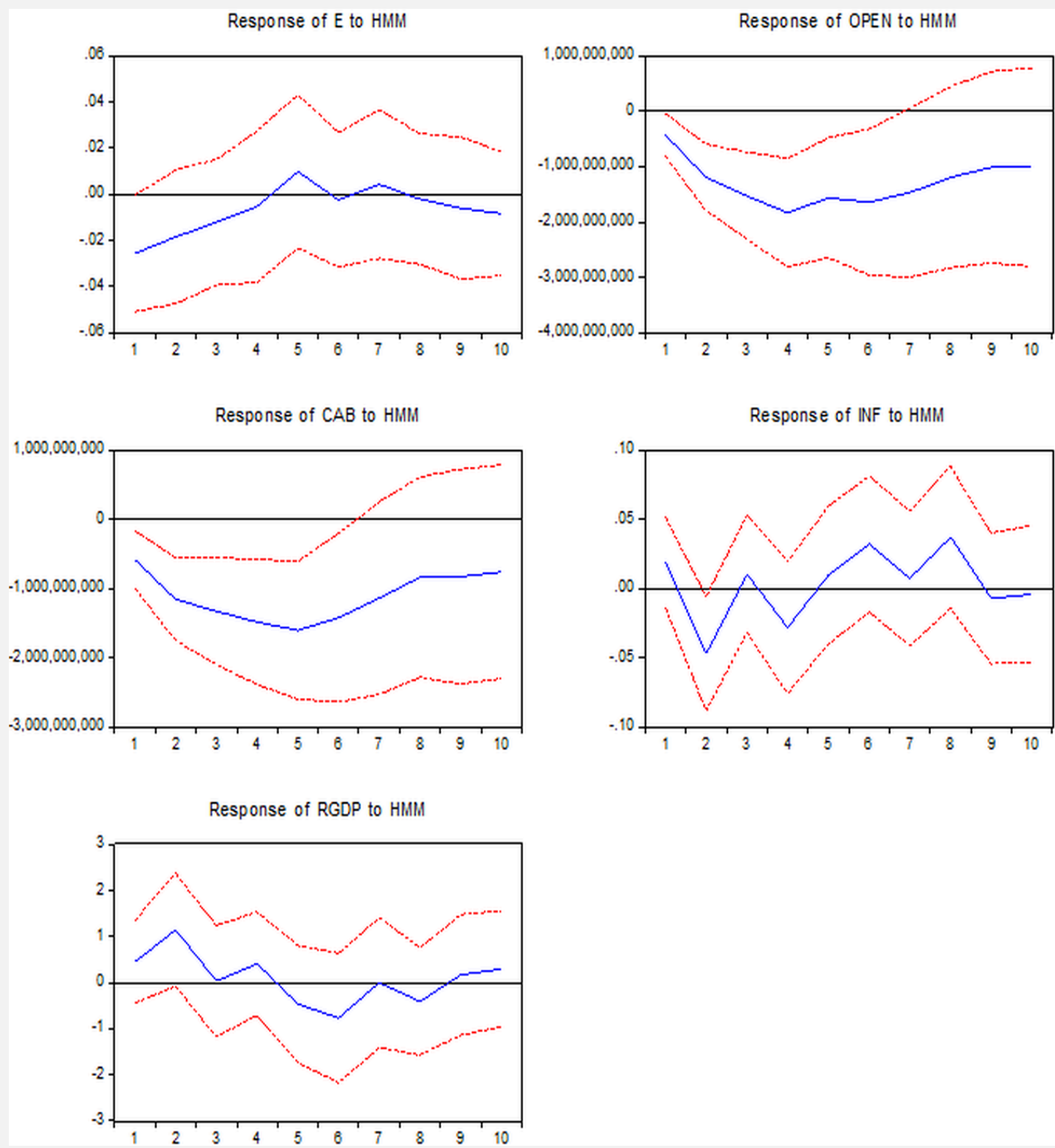
According to Figure 1 (above), the effect of hot money movement on growth (rgdp) is positive in the beginning although this positive effect returns to negative starting from the fifth period, at the end of the tenth period the growth gives positive reaction again. The inflation (inf) between the first and second period, reacts to hot money movement by sharply descending. After that, between the third and fourth period it reacts to hot money movement by increasing sharply. In the fifth period, the inflation reacts to hot money movement positively and in the last period this reaction returns to negative. During 10 periods the reaction of real sector pre-crisis indicators; growth and inflation is up and down and unstable. In 10 periods, the hot money movement effects both the inflation and growth positively and increasingly in general. As a result, the hot money movement causes fluctuation and instability on both of these indicators.

The variance decomposition is an approach that targets to define the relationships of macro-variables. In variance decomposition; the change in variance is examined to define how much of this change (in percentage) occurred by the variance itself and how much (in percentage) of it occurs by the effect of other variances (Tarı, 2015). The fundamental reason of VAR (4) model variance decomposition is to reveal the effect of hot money on current account and real sector indicators.

\begin{tabular}{lrrrrrr}
\hline & \multicolumn{6}{c}{ Table 10: $V a r i a n c e$ decomposition of current account balance } \\
Period & HMM & $E$ & OPEN & CAB & INF & RGDP \\
\hline 1 & 8.279522 & 9.335518 & 61.55717 & 20.82779 & 0.000000 & 0.000000 \\
2 & 20.93126 & 7.640864 & 57.93176 & 12.99184 & 0.332096 & 0.172171 \\
3 & 29.01176 & 6.869367 & 54.67017 & 9.013945 & 0.287389 & 0.147375 \\
4 & 37.39657 & 7.359322 & 47.11191 & 7.502390 & 0.431414 & 0.198397 \\
5 & 44.26402 & 9.999274 & 39.02371 & 6.129474 & 0.407625 & 0.175899 \\
6 & 48.34712 & 11.21034 & 34.25529 & 5.490665 & 0.482735 & 0.213848 \\
7 & 50.19279 & 12.02497 & 31.56577 & 5.492102 & 0.464419 & 0.259953 \\
8 & 50.25701 & 13.40162 & 29.80401 & 5.826622 & 0.458254 & 0.252482 \\
9 & 50.42848 & 14.92062 & 28.32158 & 5.540955 & 0.506701 & 0.281656 \\
10 & 50.53192 & 16.06916 & 27.17761 & 5.326901 & 0.617513 & 0.276889 \\
\hline
\end{tabular}

When Table 10 and Table 11 is analyzed, at the end of ten period, the changes that occur in the current account balance (cab) and foreign trade deficit (open) variances can mostly be explained by the hot money movement (hmm). In the Variance Decomposition results; the hot money movement is the most effective indicator on the current account balance and foreign trade deficit and this result coincide with the cause and effect results.

In the VAR (4) Model cause and effect results; the negative reaction of the current account deficit (cab) and foreign trade deficit (open) to hot money movement (hmm) in the beginning continues and exists during the period.

\begin{tabular}{lrrrrrr}
\hline \multicolumn{7}{c}{ Table 11: Variance decomposition of foreign trade } \\
Period & HMM & $E$ & OPEN & CAB & INF & RGDP \\
\hline 1 & 5.207899 & 14.05958 & 80.73252 & 0.000000 & 0.000000 & 0.000000 \\
2 & 19.76466 & 12.14884 & 65.79045 & 1.707580 & 0.152981 & 0.435485 \\
3 & 29.95487 & 11.48049 & 55.85825 & 1.867347 & 0.261513 & 0.577532 \\
4 & 40.87141 & 10.77494 & 45.67024 & 1.645668 & 0.278266 & 0.759477 \\
5 & 44.93721 & 12.42225 & 39.24028 & 2.493216 & 0.281017 & 0.626025 \\
6 & 48.87426 & 14.05159 & 33.67688 & 2.429452 & 0.376496 & 0.591321 \\
7 & 51.33741 & 15.24147 & 30.18799 & 2.248200 & 0.345863 & 0.639062 \\
8 & 52.35511 & 16.04600 & 28.10192 & 2.501191 & 0.353942 & 0.641831 \\
9 & 52.26209 & 17.27567 & 26.46781 & 2.973253 & 0.367380 & 0.653794 \\
10 & 52.16483 & 18.78914 & 25.08375 & 2.898373 & 0.433999 & 0.629904 \\
\hline
\end{tabular}




\begin{tabular}{|c|c|c|c|c|c|c|}
\hline \multirow[b]{2}{*}{ Period } & \multirow[b]{2}{*}{$\mathrm{HMM}$} & \multicolumn{5}{|c|}{ Variance decomposition of foreign currency exchange } \\
\hline & & $\mathrm{E}$ & OPEN & $C A B$ & INF & RGDP \\
\hline 1 & 6.513374 & 93.48663 & 0.000000 & 0.000000 & 0.000000 & 0.000000 \\
\hline 2 & 8.885109 & 90.53328 & 0.013082 & 0.392209 & 0.000245 & 0.176077 \\
\hline 3 & 9.724854 & 88.35640 & 0.219251 & 1.126015 & 0.048875 & 0.524608 \\
\hline 4 & 9.443389 & 85.72360 & 2.041992 & 1.796155 & 0.437519 & 0.557341 \\
\hline 5 & 9.851367 & 83.54479 & 2.137000 & 1.729736 & 1.050169 & 1.686938 \\
\hline 6 & 9.717802 & 83.28670 & 2.351503 & 1.868399 & 1.097340 & 1.678255 \\
\hline 7 & 9.674245 & 82.81702 & 2.487258 & 1.871721 & 1.497984 & 1.651767 \\
\hline 8 & 9.588859 & 82.20632 & 2.844633 & 1.894896 & 1.567081 & 1.898207 \\
\hline 9 & 9.629246 & 81.69037 & 3.178423 & 1.858936 & 1.712348 & 1.930676 \\
\hline 10 & 9.980613 & 80.84925 & 3.590698 & 1.960161 & 1.694381 & 1.924896 \\
\hline
\end{tabular}

According to Table 12, at the end of 10 periods, the foreign exchange rate (e) -another current account pre-crisis indicator- is mostly affected by hot money movement, after itself. The hot money movement is almost $10 \%$ effective on the foreign exchange rate at the end of 10 periods.

\begin{tabular}{lrrrrrr}
\hline \multicolumn{7}{c}{ Table 13: Variance decomposition of growth } \\
\hline Period & HMM & $\mathrm{E}$ & OPEN & CAB & INF & RGDP \\
\hline 1 & 1.375208 & 29.38429 & 2.077686 & 0.046460 & 0.063577 & 67.05277 \\
2 & 8.956216 & 26.22195 & 4.212115 & 0.328302 & 0.473091 & 59.80832 \\
3 & 8.802332 & 25.76167 & 5.812999 & 0.379223 & 0.465601 & 58.77818 \\
4 & 9.259267 & 25.12433 & 8.434551 & 0.910070 & 0.499941 & 55.77184 \\
5 & 7.757803 & 32.45887 & 7.981066 & 1.437972 & 0.406249 & 49.95805 \\
6 & 9.799217 & 31.25885 & 8.360561 & 1.385168 & 0.525596 & 48.67061 \\
7 & 9.742160 & 31.07744 & 8.413602 & 1.651270 & 0.538785 & 48.57674 \\
8 & 10.10550 & 30.83144 & 9.155786 & 1.755670 & 0.778082 & 47.37351 \\
9 & 9.745776 & 31.02109 & 9.216980 & 1.675665 & 0.845192 & 47.49530 \\
10 & 9.957790 & 30.73702 & 9.409397 & 1.682125 & 0.885199 & 47.32847 \\
\hline
\end{tabular}

According to Table 13 and Table 14, the changes that occur in the real sector pre-crisis indicators; growth (cab) and inflation (open) variance can mostly be explained by foreign currency exchange rate (e) after themselves at the end of 10 periods. Variance decomposition results, the effect of hot money on growth and inflation found to be not much. In the VAR (4) Model cause and affect results, the impermanent reaction given by the pre-crisis real sector indicators coincide with this result.

\begin{tabular}{lrrrrrr}
\hline \multicolumn{7}{c}{ Table 14: Variance decomposition of inflation } \\
\hline Period & HMM & $\mathrm{E}$ & OPEN & CAB & INF & RGDP \\
\hline 1 & 1.761644 & 23.60522 & 7.158460 & 0.002302 & 67.47237 & 0.000000 \\
2 & 10.67834 & 21.45893 & 11.93011 & 0.109094 & 55.73058 & 0.092938 \\
3 & 10.66503 & 21.01196 & 13.65588 & 0.151997 & 53.46725 & 1.047868 \\
4 & 11.79739 & 23.88348 & 12.28750 & 1.391954 & 49.43527 & 1.204399 \\
5 & 10.47861 & 23.56186 & 10.71728 & 1.261017 & 52.36670 & 1.614529 \\
6 & 12.97039 & 22.72235 & 10.75673 & 1.271373 & 50.69080 & 1.588350 \\
7 & 12.92009 & 22.43415 & 10.67681 & 1.341413 & 50.25557 & 2.371967 \\
8 & 15.20906 & 20.42132 & 9.738398 & 1.531825 & 50.78093 & 2.318468 \\
9 & 14.90209 & 20.22049 & 9.732792 & 1.489077 & 50.80378 & 2.851761 \\
10 & 14.86307 & 20.17279 & 9.695797 & 1.499112 & 50.80135 & 2.967880 \\
\hline
\end{tabular}




\subsection{THE CONCLUSION AND DISCUSSION}

In Turkish economy, an important rate of hot money inflow occurred after the abolition of restrictions on capital movement in 1989. The outflow of hot money, which causes increase in demand, growth and monetary expansion, caused negative results. The hot money flowing to Turkey caused crisis, in connection with the high arbitrage return between the interest rates and foreign Exchange rates. As in 1994, 2000/2001 and 2008 crisis, the high rate of hot money outflow caused the crisis in the country. (Üçer, Rijckeghem \& Yolalan, 1998), (Gerni, Selçuk \& Değer, 2005) and (Avcl, Altay 2013) also expressed that hot money flow is an important pre-crisis indicator for Turkish economy.

The VAR (4) model in our study reveals that the hot money movement negatively effects the current account pre-crisis indicators. The hot money movement causes instabilities in real sector pre-crisis indicators. These results from The VAR (4) model cause and effect functions are supported by the variance decomposition analysis. Similar results are stated in the studies of (Corbo, Hernandez 1996), (Yeldan, 1996) and (Rodrik, Velasco 1999).

In conclusion, the hot money movement in Turkey is an ineffective policy tool on the current account and real sector pre-crisis indicators. The economy policy makers should not trust to hot money movement and use alternative policy tools.

In Turkey, after 1989, the year which restrictions on capital movement are abolished, the major problem is insufficient savings. The capital flowing to the country for financing the deficit is short term and speculative hot money movement so it only can create a temporary stability. The sudden outflow of foreign capital from the country can change the short-term stability of the economy to opposite as occurred in 1994, 2000-2001 and 2008 crisis. In that point, the economic decision making mechanisms should consider the policy targets of employment, exports and investments and if necessary interfere to the movement of capital.

In Turkish economy, low level of direct foreign investment is an important problem. After 1989, the year which restrictions on capital movement are abolished the direct foreign investment increased. However, it is examined that this increase was low compared to hot money flow. In that sense, economic decision-making mechanisms should support the direct foreign investment more.

\section{REFERENCES}

Altıntaş, H., Öz, B. (2007). Predicting currency crises with signals approach: The case Of Turkey. Anadolu University Journal of Social Sciences, 7(2), 19-44.

Avcı, M.A., Altay, N.O. (2013). Finansal Krizlerin Sinyal Yaklaşımı ile Öngörülmesi: Türkiye, Arjantin, Tayland ve İngiltere i̇çin Bir Analiz. Pamukkale Üniversitesi Sosyal Bilimler Enstitüsü Dergisi, 14(1), 4758.

Boratav, K. (2009). Türkiye iktisat tarihi: 1908-2007. Ankara: Imge Kitabevi.

Boratav, K. (2011). Bir krizin kısa hikâyesi (2). Ankara: Arkadaş Yayınevi

Corbo, V., Hernandez, L. (1996). Macroeconomic adjustment to capital inflows: lessons from recent Latin American and East Asian experience. The World Bank Research Observer, 11(1), 61-85.

Corsetti, G., Pesenti, P., Roubini, N. (1998). Fundamental determinants of the Asian crisis: a preliminary empirical assessment. Unpublished manuscript (New Haven, New York, New York: Yale University and University of Bologna, Federal Reserve Bank of New York and NBER).

Çeviş, i. (2005). Para krizlerine ampirik bir yaklaşım. Ankara: Sermaye Piyasası Kurulu.

Frankel, J.A., Rose, A.K. (1996). Currency crashes in emerging markets: An empirical treatment. Journal of International Economics, 41(1), 351-366.

Gerni, C., Selçuk, E., Değer, M.K. (2005). Erken uyarı sistemleri yoluyla Türkiye'deki ekonomik krizlerin analizi. Ekonometri ve Istatistik Dergisi, 2(1), 39-62. 
Gujarati, D.N. (2003). Basic econometrics (4). McGraw Hill.

Insel, A., Sungur, N. (2003). Sermaye akımlarının temel makroekonomik göstergeler üzerindeki etkileri: Türkiye örneği-1989: III-1999: IV (No. 2003/8). Discussion Paper, Turkish Economic Association.

Kaminsky, G., Lizondo, S., Reinhart, C.M. (1998). Leading indicators of currency crises. Staff Papers, 45(1), 1-48.

Karaçor, Z., Alptekin, V. (2006). Finansal krizlerin önceden tahmin yoluyla değerlendirilmesi: Türkiye örneği. Celal Bayar Üniversitesi Iktisadi ve Idari Bilimler Fakültesi Dergisi, 13(2), 231-256.

Karluk R.S. (2014). Türkiye ekonomisi cumhuriyetin ilanından günümüze yapısal dönüşüm (13). İstanbul: Beta Basın Yayım.

McKinnon, R. (1973). Money and capital in economic development. Washington: The Brookings Institution.

Mercan, M., Peker, O. (2013). Finansal gelişmenin ekonomik büyümeye etkisi: ekonometrik bir analiz. Eskişehir Osmangazi Üniversitesi İktisadi ve İdari Bilimler Dergisi, 8(1), 93-120.

Oktar S., Dalyancı, L. (2010). Finansal kriz teorileri ve Türkiye ekonomisinde 1990 sonrası finansal krizler. Marmara Üniversitesi Iktisadi ve Idari Bilimler Fakültesi Dergisi, 29(2), 1-22

Rodrik, D., Velasco, A. (1999). Short-term capital flows (No. w7364). National Bureau of Economic Research.

Sevüktekin, M., Nargeleçekenler, M. (2010). Ekonometrik zaman serileri analizi (3). Ankara: Nobel Yayıncilık.

Seyidoğlu, H., Yıldız, R. (2006). Ekonomik kriz öncesi erken uyarı sistemleri: Makale derlemesi (1). İstanbul: Arıkan Yayınevi.

Shaw, E. (1973). Financial development in economic development. Oxford University Press, New York.

Tarı, R. (2015). Ekonometri (11). Umuttepe Yayınları.

Turgut, A. (2007). Türleri, nedenleri ve göstergeleriyle finansal krizler. TÜHis iş Hukuku ve iktisat Dergisi, 20 (4-5), 35-46.

Uzunoğlu, S., Alkın, K., Gürlesel, F. (1995). Uluslararası sermaye hareketlerinin gelişmekte olan ülkelerde makroekonomik etkileri ve Türkiye. İstanbul: IMKB Yayınları.

Üçer, M., Rijckeghem, C. V., Yolalan, R. (1998). Leading indicators of currency crises: a brief literature survey and an application to Turkey. Yapi Kredi Economic Review, 9 (2), 3-23.

Williamson, J., Mahar, M. (2002). Finansal Liberalizasyon Üzerine Bir Inceleme. (Translation: G. Delice). Ankara: Liberete Yayınları.

Yeldan, E. (1996). Kısa vadeli sermaye akımlarının Türk finans piyasalarına olan etkileri üzerine gözlemler. Ekonomide Durum, 4(1), 41-49.

Zivot, E., Andrews, D. W. K. (2002). Further evidence on the great crash, the oil-price shock, and the unit-root hypothesis. Journal of business \& economic statistics, 20(1), 25-44. 